American Journal of Environmental Sciences 6 (3): 204-211, 2010

ISSN 1553-345X

(C) 2010 Science Publications

\title{
Laboratory Scale of Liquid Coal Fuel Combustion Process and Exhaust Gas Formation
}

\author{
${ }^{1}$ Kartika Kus Hendratna, ${ }^{2}$ Osami Nishida, ${ }^{2}$ Hirotsugu Fujita and ${ }^{2}$ Wataru Harano \\ ${ }^{1}$ Energy Research Engineering Laboratory, Department of Marine Engineering, \\ Graduate School of Maritime Sciences, Kobe University, 5-1-1 Fukae Minamimachi, \\ Higashinada-Ku, Kobe-Japan 658-0022 \\ ${ }^{2}$ Department of Marine Engineering, Faculty of Maritime Sciences, Kobe University, Japan
}

\begin{abstract}
Problem statement: Much research of coal has been already undertaken to ascertain the possibilities of coal being used as substitute for heavy fuel oil in the transportation sector. The effects of using coal as transportation fuel to the environment must also be considered. This study will review several aspects of the coal oil combustion process including combustion behavior, flame stability, some emissions from exhaust gas; $\mathrm{CO}, \mathrm{NO}_{\mathrm{x}}$ and the particulate matter in a well insulated laboratory scale furnace for more stable of combustion. Approach: New way for preparation for liquid coal oil steady combustion on a $2.75 \mathrm{~m}$ horizontal boiler with four annular segment tubes, a water jacket system and a system for measurement of water temperature inside was archived. Data was gained by applying liquid coal in the experiment. Detailed preparation and setting for steady combustion of coal oil and formation of the exhaust gas were discussed based on data sampling from four sample points in each centre of the angular tube segments. Results: Preparation for coal oil combustion is an important point in the successful of combustion. Heating coal fuel to than $100^{\circ} \mathrm{C}$, heating the fuel line to the same temperature and providing enough air pressure for atomization of coal oil until $0.1 \mathrm{MPa}$ allows coal fuel smoothly atomized in the semi gas phase. There was enough of air combustion via a blower with $4500 \mathrm{~L} \mathrm{~min}^{-1}$ of flow rate and a $24 \mathrm{~L} \mathrm{~min}^{-1}$ of water flow rate in the water jacket transforms the energy of the fuel to the heat. Uncolored of the exhaust gas and the physical inspection describes the completion of combustion. This result close-relates with the pollutants formation in the exhaust gas. Conclusion: By conducting a deep research process, there is a chance for the substitute of heavy fuel oil with liquid coal fuel with no special treatment needed in combustion process without ignoring the contribution of the combustion results as an environmental problem.
\end{abstract}

Key words: Coal oil, furnace, combustion, exhaust gas

\section{INTRODUCTION}

Coal is believed by some to be one of the energy sources for the future, besides alternative energy and others renewable energy sources. The availability of coal as a fossil fuel is approximately predicted to be up to three times in normal use. There are coal deposits in many countries, which is an enormous estate advantage in comparison to crude oil and natural gas. In the transportation sector, finding new substitutes for fossil fuel and its derivative fuel is urgently needed and without ignoring the contribution of combustion results on the environmental problems. The transportation sector contributes the second largest source of global warming after industrial sector. Coal has similar characteristics to fossil fuel. Coal is defined as sedimentary rock whose content is a heterogeneous mixture of organic and inorganic constituents containing intimately mixed solid, liquid and the gaseous phase (Rajender, 2007). It is composed primarily of carbon along with assorted other elements, including sulfur. It also contains a considerable amount of incidental moisture, which is the water trapped within the coal and in-between the coal particles (Rajender, 2007).

Coal oil is categories as heavy fuel, in same grade with other residual of fossil fuel. Special treatment is needed in order to completely burns and transform the energy inside. Nowadays, coal is expected as the second option of energy source for future transportation. Coal as an alternative energy resource is an attractive technology since it is well developed and

Corresponding Author: Kartika Kus Hendratna, Energy Research Engineering Laboratory, Department of Marine Engineering, Graduate School of Maritime Sciences, Kobe University, 5-1-1 Fukae Minamimachi, Higashinada-Ku, Kobe-Japan 658-0022 
thus could be implemented fairly and rapidly. There are comparatively large quantities of coal reserves and its contents less of sulfur that minimizes the formation of $\mathrm{SO}_{\mathrm{x}}$ (Michael and Lester, 1994). Many countries have conducted experiment for the possibility of using coal as second alternative fuel for ships and others long distance sea transportation. It can reduce the operational cost. In this study, the pollutants formation for a stable condition of liquid coal fuel, preparation of the combustion process and the condition parameters of the combustion are reported.

Coal liquefaction: Coal liquefaction is the process of conversion of coal into synthetic oil. Coal would be gasified to make syngas (a balanced purified mixture of $\mathrm{CO}$ and $\mathrm{H}_{2}$ gas) and the syngas is then condensed, using catalysts to make light hydrocarbons. These can be further processed into lighter fuel. Syngas can also be converted to methanol, which can be used as a fuel, fuel additive, or converted into coal liquid fuel. There are two different methods for converting coal into liquid fuels.

Direct liquefaction: This liquefaction works by dissolving the coal in a solvent at high temperature and pressure. This process is generally achieved by reacting coal as slurry in a process-derived solvent. Different processes may use only hydrogen with the solvent and may operate with or without a reaction catalyst. The process conditions used for this step vary considerably, with temperatures in the range of $300-400^{\circ} \mathrm{C}$ and pressures of 50-300 bar (Masaharu, 2003). Processes that do not use hydrogen at this point tend to operate at low pressures. The more severe conditions are generally associated with processes that carry out both the dissolution of the coal and the hydrocracking of the dissolved products.

Indirect liquefaction: This process was mainly consisted of the complete breakdown of the coal structure by gasification and with steam and oxygen. The composition of gasification products is adjusted to filling the required mixture of hydrogen and carbon monoxide and cleaned to remove the sulfur containing catalyst. This leads for producing high quality and ultra-clean products. In the synthesis step, the resulting synthesis gas is reacted over a catalyst, but at a relatively low pressure operating temperatures in the range of $200-350^{\circ} \mathrm{C}$, with operating pressures in the range of 20-30 bars (Masaharu, 2003).

Fuel for experiments was JBO coal fuel, produced by JFE Chemical Co. Japan. The process of JFO production is categorized as direct liquefaction. Detail of the liquid coal fuel (JBO) production process can be seen in Fig. 1. From the coal tar tank, coal was supplied to a continuous tar distillation process system and then followed by the naphthalene distillation process which fraction process was undertaken. Slurry from a continuous tar distillation process was treated by using the particle elimination device to eliminate particles inside and naphthalene left in the process was directly come to the tank for mixing process. JBO coal oil was created from the mixing of $\mathrm{NWO}$, antrasen and naphthalene.

Physically, the fuel was high density, black in color and strong in smell and is not easily transported at room temperature. The properties of JBO coal fuel can be seen in Table 1.

Preparation and support system: The boiler is an enclosed vessel that provides for combustion. The product of heat is transferred into water, until it becomes heated water or steam. Boilers are vulnerable to conditions such as the tube fouling; this may reduce their efficiency over relatively short periods of time and also water flow, in the water jacket system. Process of preparation is important in order to set and construct the system and all the supporting parts in the combustion process. Main component into the boiler are the feed water system, the air system and the fuel system.

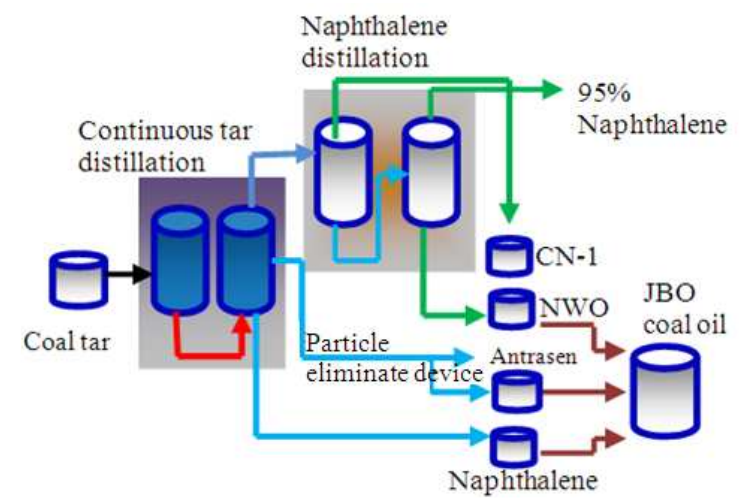

Fig. 1: JBO coal process

Table 1: Properties of JBO coal fuel

\begin{tabular}{llr}
\hline Components & Unit & Amount \\
\hline Density $\left(15 / 4^{\circ} \mathrm{C}\right)$ & $\mathrm{g} \mathrm{cm}^{-3}$ & 1.1937 \\
Kinematic viscosity & $\mathrm{cSt}$ & 100.0000 \\
Residual carbon & $\mathrm{Wt} \%$ & 250.0000 \\
Flash point & ${ }^{\circ} \mathrm{C}$ & 116.0000 \\
Pour point & ${ }^{\circ} \mathrm{C}$ & -7.5000 \\
$\mathrm{H}_{2} \mathrm{O}$ & $\mathrm{Vol} \%$ & 0.1000 \\
Ash content & $\mathrm{Vol} \%$ & 0.0500 \\
Sulfur & $\mathrm{Vol} \%$ & 0.5000 \\
$\mathrm{~N}$ & $\mathrm{Vol} \%$ & 0.7200 \\
Vanadium & $\mathrm{Vol}^{\circ} \%$ & 0.0000 \\
High calorific value & $\mathrm{MJ} \mathrm{kg}^{-1}$ & 38.2600 \\
Low calorific value & $\mathrm{MJ} \mathrm{kg}^{-1}$ & 37.1700 \\
\hline
\end{tabular}



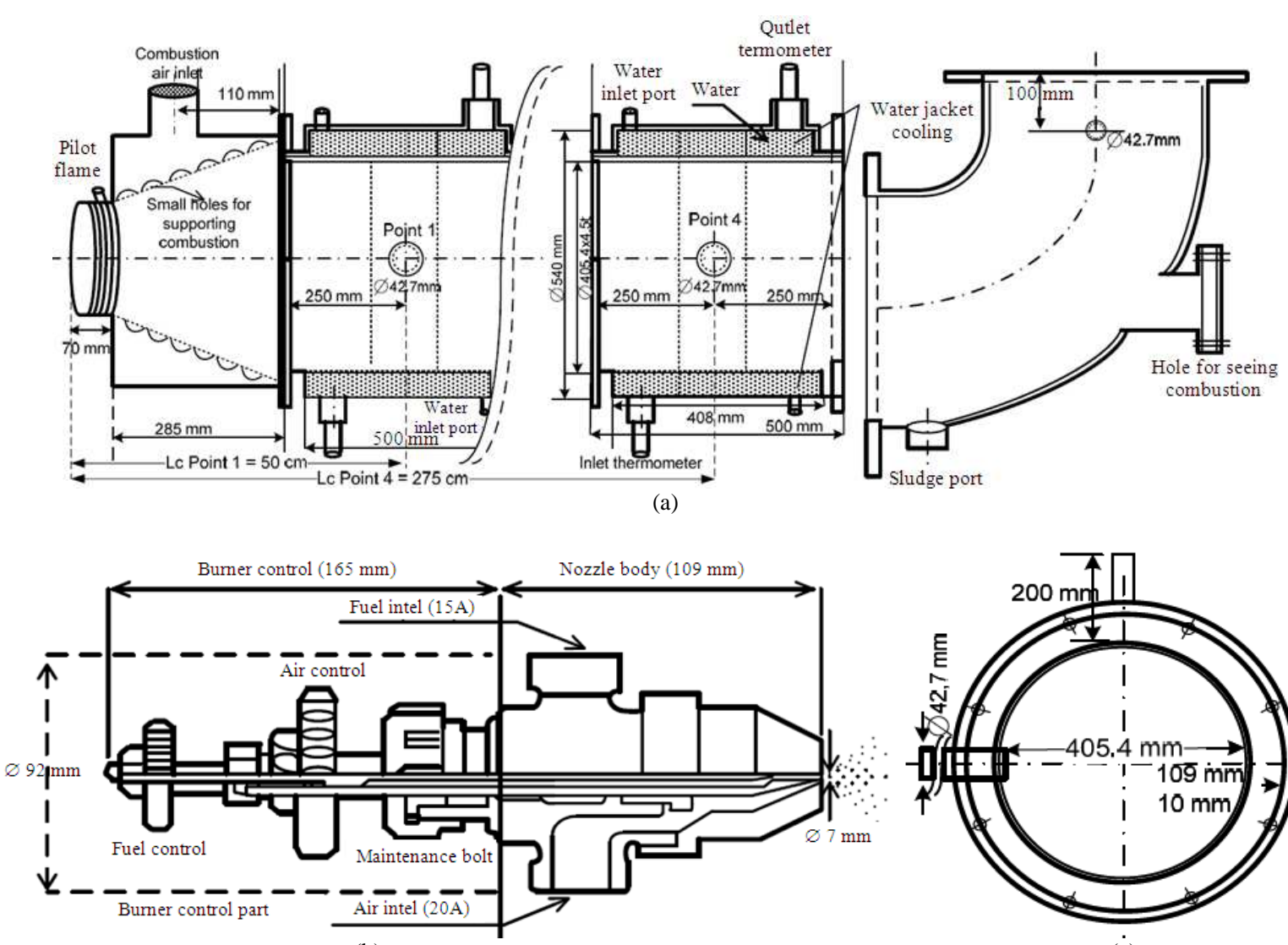

(b)

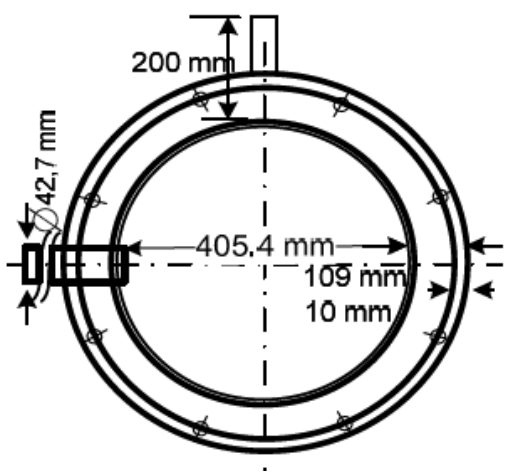

(c)

Fig. 2: (a) Drawing of burner (b) cross section of burner and (c) drawing of boiler

Heaters, pump, blower, condenser and fuel line system for transporting coal oil to the burner are normally used with these systems.

Feed water system provides water to the boiler. The flow rate of the water inlet was monitored for measuring heat release from combustion, for transferring heat from flue gases to the water inside the boiler`s wall. Two thermometers were located at each of the block tube, with the water jacket system receiving heat by transfer. The block of boiler near to the burner receives the biggest heat via transfer from combustion. In the experiment, $24 \mathrm{~L} \mathrm{~min}^{-1}$ of fresh water was supplied by the media of heat transfer inside water jacket system. Figure 2 shows the detail of boiler and burner illustration.

Air is the important factor that influences the complete of combustion process. The availability of air is related with the combustion efficiency and exhaust gas formation as well (Heywood, 1988). Air is always blown to the boiler to assure that there is no unburned fuel remaining. It is also important to control air inside the burner, where its velocity can affects the turbulence in the burner. It becomes harder to get good fuel and air mixing at higher turndown ratios since the air amount is limited because of the closed arrangement. Towards, the highest turndown ratios of any burner, it becomes necessary to increase the excess air amounts to obtain enough turbulence to get a proper mixing (Heywood, 1988). Two separated systems of air for the combustion process proved important for combustion air support and for air atomization. Air atomization is used to atomize the fuel inside the burner which has a lower speed, surrounded with a high speed stream of air inside the burner. Then, air combustion in the oxygen supply that integrated into the system keeps the fuel burning. Combustion air was supplied by the operation of a blower on a series of air supply pipes, with $4500 \mathrm{~L} \mathrm{~min}^{-1}$ of flow rate. Air for atomization is gained from the operational of compressor.

Coal oil preparation includes the selection of tank material, designing a system and line heating temperature setting. Within the construction of the fuel line, there are two major consideration was taken. One, for the coal oil smoothly supply to the burner without 
any sludge inside the pipe. Another purpose is that heating of the pipe for keeping the fuel flow without any disturbance from unmovable disperses particle, which affix to the pipe walls. The entire coal oil supply system pipe is covered by $45 \mathrm{~mm}$ in width and $500 \mathrm{~mm}$ length of rope heaters on which the entire normally will be heated up to $130^{\circ} \mathrm{C}$ and automatically control by a unit on the digital control panel. For steady combustion, the temperature of tank was set at $80^{\circ} \mathrm{C}$, the pressure of fuel inlet burner was on $0.08 \mathrm{Mpa}$ and water flow rate was $23.3 \mathrm{~L} \mathrm{~min}$. Detailed of steady combustion parameters condition are described in Table 2 .

Table 2: Steady combustion parameters condition

\begin{tabular}{|c|c|c|}
\hline Components & MDO & Coal oil \\
\hline $\begin{array}{l}\text { Water cooling (ON/OFF), } \\
\text { Flow rate }\left(\mathrm{L} \mathrm{min}^{-1}\right)\end{array}$ & $23.4 \mathrm{~L} \mathrm{~min}^{-1}$ & $23.3 \mathrm{~L} \mathrm{~min}^{-1}$ \\
\hline Exhaust gas fan (On/OFF) & On & On \\
\hline $\begin{array}{l}\text { Tank heating }(\mathrm{ON} / \mathrm{OFF}) \text {, } \\
\text { Temperature }\left({ }^{\circ} \mathrm{C}\right)\end{array}$ & Off & On $\left(80^{\circ} \mathrm{C}\right)$ \\
\hline $\begin{array}{l}\text { Fuel line heating }(\mathrm{ON} / \mathrm{OFF}) \text {, } \\
\text { Temperature }\left({ }^{\circ} \mathrm{C}\right)\end{array}$ & Off & On $\left(120^{\circ} \mathrm{C}\right)$ \\
\hline Pressure from compressor (MPa) & 0.1 & 0.1 \\
\hline Pressure inlet of burner (MPa) & 0.07 & 0.08 \\
\hline Temperature inlet of burner $\left({ }^{\circ} \mathrm{C}\right)$ & 18 & 90 \\
\hline Heater setting of inlet burner $\left({ }^{\circ} \mathrm{C}\right)$ & Off & On $\left(110^{\circ} \mathrm{C}\right)$ \\
\hline Pressure of fuel oil (MPa) & 0.06 & 0.08 \\
\hline Pump flow rate (Hezt) & 50 & 60 \\
\hline Water jacket cooling inlet $\left({ }^{\circ} \mathrm{C}\right)$ & 12 & 14 \\
\hline Water jacket cooling outlet $\left({ }^{\circ} \mathrm{C}\right)$ & 49 & 55 \\
\hline
\end{tabular}

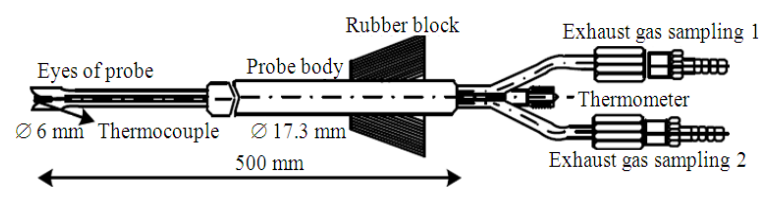

Fig. 3: Sampling probe illustration

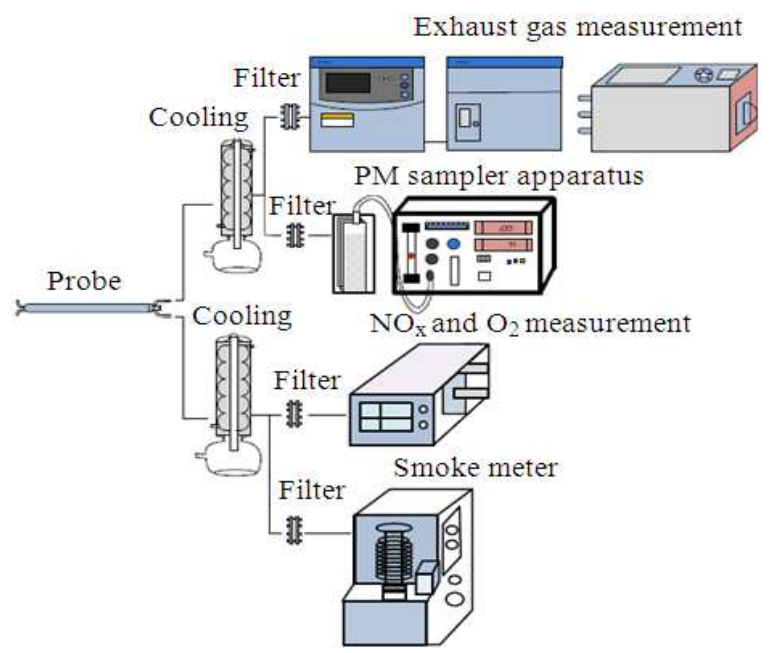

Fig. 4: Measurement equipments
Gas, liquid and solid samples were removed from the combustion zone and water-quenched by using a stainless steel sampling probe with $6 \mathrm{~mm}$ exhaust gas inlet $500 \mathrm{~mm}$ length, produced by Akano illustrated in Fig. 3. A thermocouple for temperature measurement on real time sampling is located in the tail of the eyes probe. Sampled exhaust gas flow to different water cooling system to turn down the temperature of exhaust gas before measurement process begin.

\section{MATERIALS AND METHODS}

The system in the experiment has two main lines; Light oil and Coal oil. All lines were designed as an independent system and have no relation to each other. Light oil is used in the beginning and the end of an experiment for a cleansing process, this within $10 \mathrm{~min}$ of combustion. While no heating process in the whole of the fuel oil's line. When the coal oil is supplied to the burner, heating is the important in order to make liquid coal fuel easier to flow inside pipes. High viscosity of coal fuel must be lowered by heating process. Sampling point for data was created as 60, 110, 160,210 and $270 \mathrm{~cm}$ from the centre of burner (Lc). The sample hole was created with $42.7 \mathrm{~mm}$ in diameter, further the probe was inserted to $202.5 \mathrm{~mm}$, the centre of the boiler.

The heating temperature for the coal tank and fuel line was set at $120^{\circ} \mathrm{C}$. A fuel gear pump is operated at $50 \sim 60 \mathrm{~Hz}$ with average of fuel flow rate at $2.5 \mathrm{~L} \mathrm{~min}^{-1}$. Two strainers are located before the burner to sludge the macro-molecules inside the oil. In order to keep the pressure in constant flow, a compressor with $0.2 \mathrm{MPa}$ of pressure capacity was used to supply $0.08 \mathrm{MPa}$ pressure air to high pressure air drum, then transferred to the burner to keep a steady supply of air for atomization. Detail of the system use to support liquid coal combustion in the experiment can be seen in Fig. 5. Probe is put in each of the sampling point hole to get a sample data. The high temperature of exhaust gas must be cooled down before entering a measurement tools needed for the consistence data collection in the measurement process. Two century water coolers were used for cooling and followed by filtering system, to catch disperse particles and minimize particles in the gas sampler equipments. PM concentration is collected by using composite filter study with diameter $45 \mathrm{~mm}$ and gas sampling flow rate at $20 \mathrm{~L}$ with $12 \mathrm{~L} \mathrm{~min}^{-1}$. For gas contents inside exhaust gas measurement, Hodaka HT-3000 sampling equipment is used. Figure 4 shows the equipments used in the experiment. 


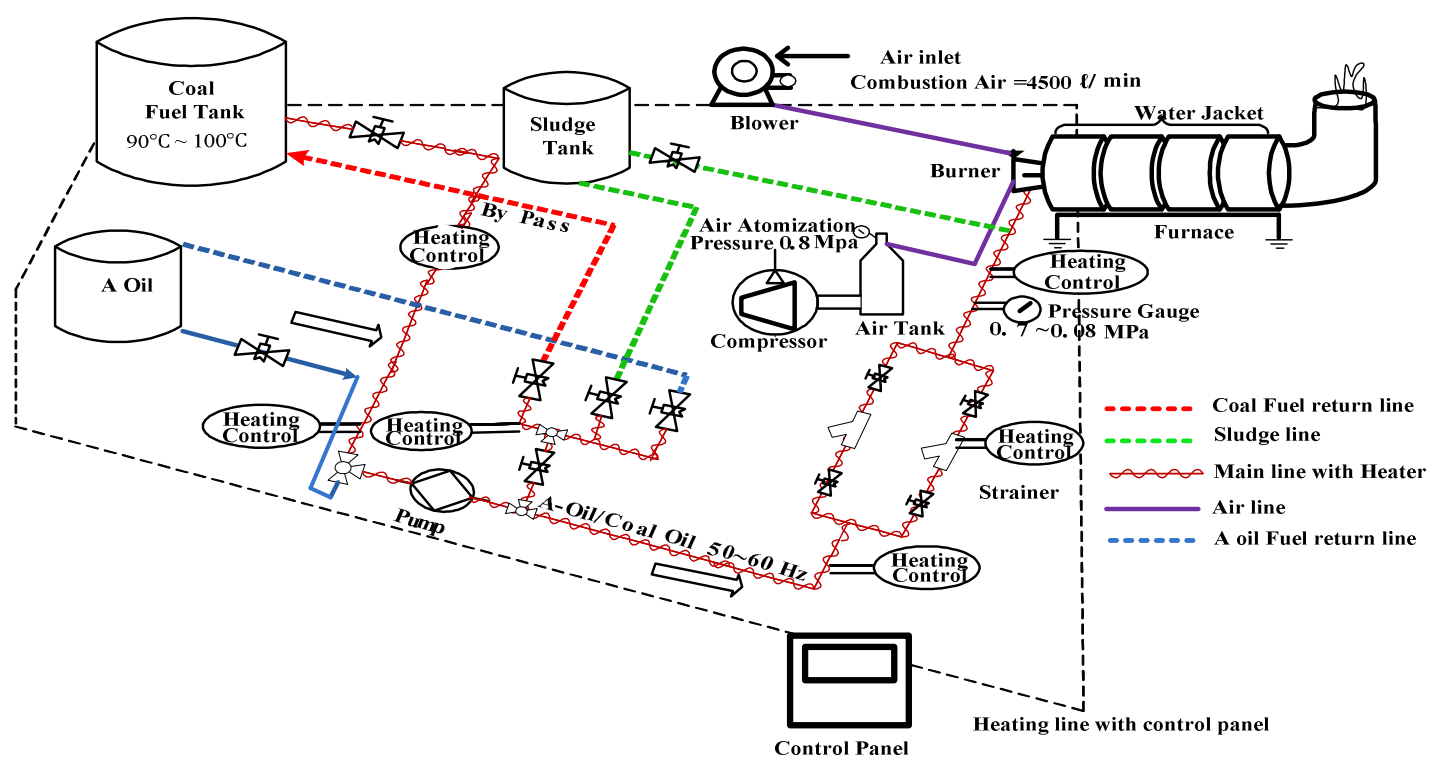

Fig. 5: System for experiment

\section{RESULTS AND DISCUSSION}

During the combustion process, only gas and Particulate were sampled and analyzed. Temperature exhaust gas and water cooling system were also measured. Combustion process was maintained in the stable condition when data collection was collected.

Visual observations of the flame during combustion were made through small windows near the end of four annular tubes. As the combustion and atomization air increased, the flame zone rose being longer in the boiler. Setting process for good mixing between air and coal fuel was the most difficult part since the fuel oil have high density and still contains small particles which flow together inside the pipe. Manual setting on burner for proper combustion took long time. If the fuel was too much atomized, the exhaust gas was black in color, but if less fuel was atomized, the exhaust gas turned into thin white. For this condition, stable flame could not be sustained. Otherwise, when proper of air and fuel were mixed, the exhaust gas was without color. Only heat flux around the wall of the exhaust gas appeared.

Air pressure also took an important role in the successful of combustion. Steady supply of air pressure for both atomization and combustion influent to the steady combustion. Air flow rate was varied to achieve the range of air/fuel stoichiometric ratios. Based on the exhaust gas color, a best visual observation of combustion was gained when the major zone of combustion was $80-90 \mathrm{~cm}$, or more, from the nozzle.
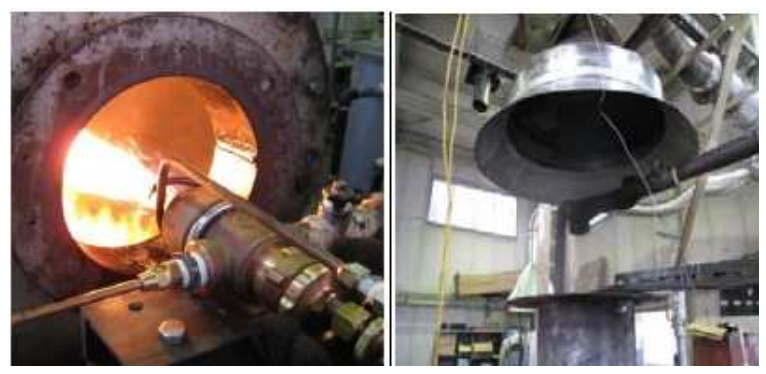

Fig. 6: Combustion and exhaust gas condition

From an observation of flame in the upside hole near the nozzle, no separation of burner nozzle and point of ignition could be observed. This indicated good combustion. The heat release rate that measured from the difference of inlet and outlet of the water cooling shows at $877.17 \mathrm{~kJ} \mathrm{~min}^{-1}$ in $60 \mathrm{~cm}$ from the centre of burner and it increase by the longer axial boiler distance $275 \mathrm{~cm}$ to $1267.03 \mathrm{~kJ} \mathrm{~min}^{-1}$. Figure 6 shows the combustion and the exhaust gas condition pictures of liquid coal oil combustion when the cover block was opened. Detailed of the condition parameters of the coal combustion, when stability is gained are listed in the Table 2.

Particulate matter: Particulate Matter (PM) contains a solid part, as well as soluble organic material and sulfuric acid. The solid part consists of carbon (soot) which it was formed during the combustion process 
(Lian et al., 2006). Primary particles formed during period of combustion, is merged by another to be agglomerate particles. Measurement of physical of pm is difficult since the agglomeration process between particles happened rapidly and in sort time.

From Fig. 7, we saw the build-up of pm mostly occurring in the rich region of combustion and as a result of incomplete combustion. Hydrocarbon inside fuel was not completely burned, which forms soluble organic fraction component. The particulate was identified at $0.948 \mathrm{~g} \mathrm{~m}^{-3}$, which inside consist $0.7225 \mathrm{~g} \mathrm{~m}^{-3}$ of soluble organic fraction and $0.2255 \mathrm{~g}$ $\mathrm{m}^{-3}$ of dry soot. Then, the increase of axial distance and end of combustion remain $0.179 \mathrm{~g} \mathrm{~m}^{-3}$ particulate which inside consist $0.104 \mathrm{~g} \mathrm{~m}^{-3}$ of soluble organic fraction and $0.0075 \mathrm{~g} \mathrm{~m}^{-3}$ of dry soot. Figure 8 indicates that the smoke percentage when combustion occurred was on axial distance (Lc) from Burner 53\% at place near the combustion region then decrease until $3 \%$ in $275 \mathrm{~cm}$ from burner.

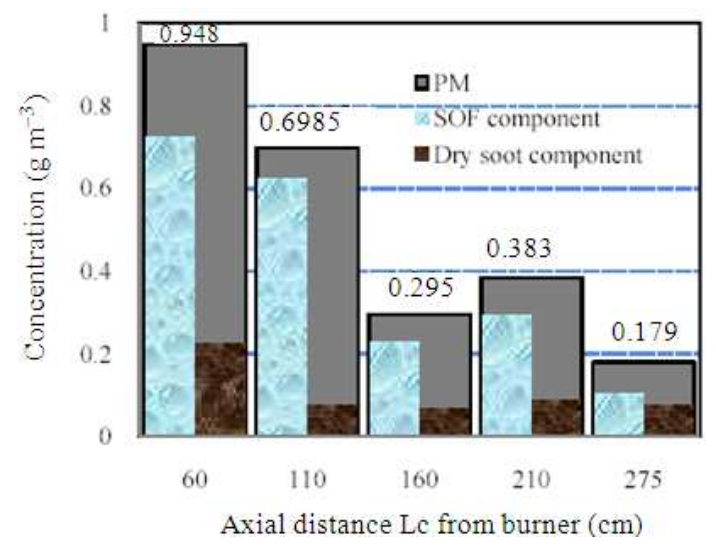

Fig. 7: particulate and its components

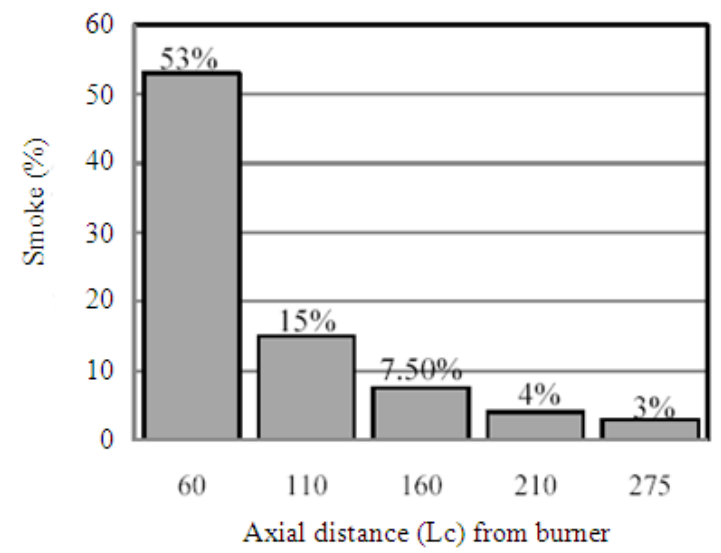

Fig. 8: Smoke
Nitrogen component: Nitrogen is considered an environment problem since it initiates reactions that result in production of ozone and acid rain. The principle pollutants generated by nitrogen are nitric acid (NO) and its derivative, collectively referred to as $\mathrm{NO}_{\mathrm{x}}$ (Pollack, 1979). In combustion, formation of $\mathrm{NO}_{\mathrm{x}}$ primarily formed in three ways; prompt $\mathrm{NO}_{\mathrm{x}}$, thermal $\mathrm{NO}_{\mathrm{x}}$ and Fuel $\mathrm{NO}_{\mathrm{x}}$. Figure 9 shows the formation for both $\mathrm{NO}$ and its derivative.

$\mathrm{NO}$ and $\mathrm{NO}_{\mathrm{x}}$ formation was formed in the same way but different in formation timing. NO forms more rapid than its derivative. From the experiment, the highest NO formation gained at $386 \mathrm{ppm}$ in the $60 \mathrm{~cm}$ from the burner then slowly turned down to $229 \mathrm{ppm}$ in the $275 \mathrm{~cm}$ from the centre of burner. There was a not big difference for the concentration of $\mathrm{NO}_{\mathrm{x}} \cdot \mathrm{NO}_{\mathrm{x}}$ was $396 \mathrm{ppm}$ at highest concentration and $242 \mathrm{ppm}$ for the lowest one.

The $\mathrm{NO}_{\mathrm{x}}$ formation cannot be separated with the temperature of combustion. Thermal $\mathrm{NO}_{\mathrm{x}}$ is formed when nitrogen and oxygen in combustion air combine with one another at the high temperature of flame (Kenneth et al., 1975). Figure 10 clearly describes the correlation between $\mathrm{NO}_{\mathrm{x}}$ formation and combustion temperature, by means of a sampling temperature. The highest $\mathrm{NO}_{\mathrm{x}}$ at $396 \mathrm{ppm}$ was measured when the temperature of sampling point was $400^{\circ} \mathrm{C}$ and it decreases to $242 \mathrm{ppm}$ while the sampling temperature was on around $240^{\circ} \mathrm{C}$.

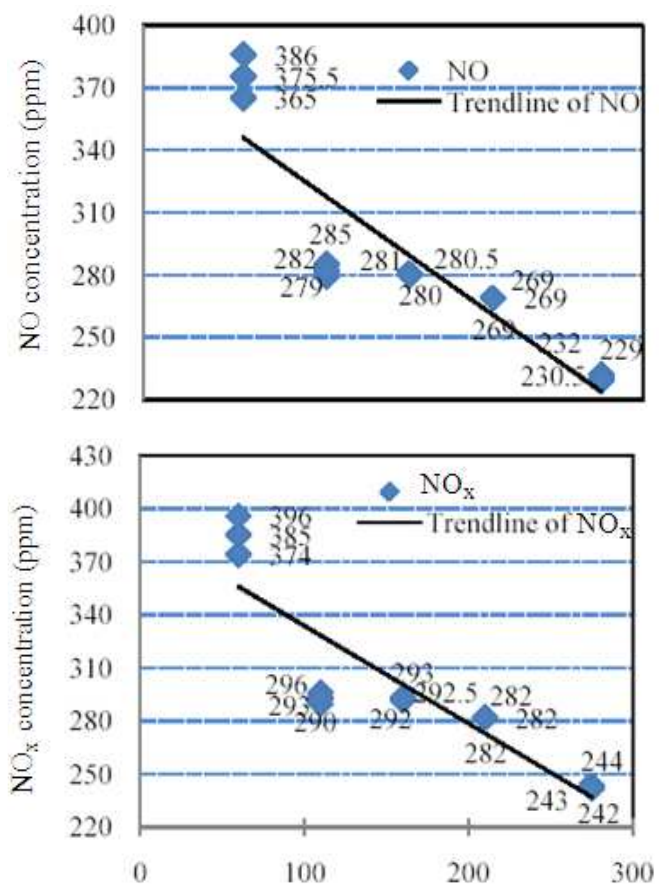

Fig. 9: $\mathrm{NO}$ and $\mathrm{NO}_{\mathrm{x}}$ emission formation 


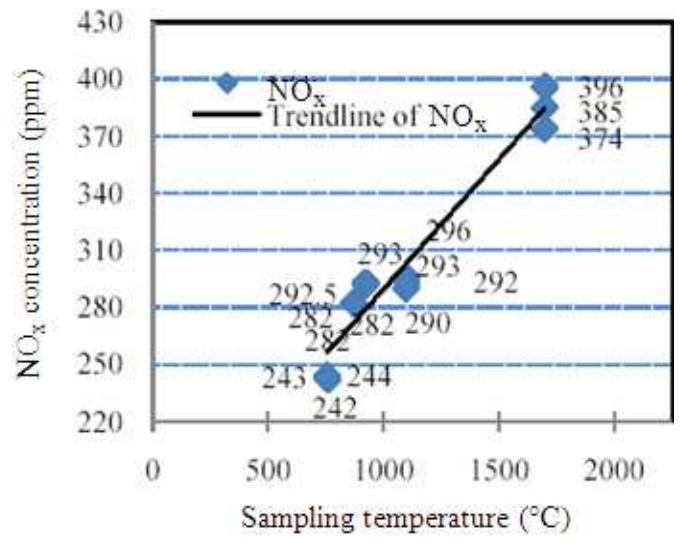

Fig. 10: $\mathrm{NO}_{\mathrm{x}}$ formation base on temperature
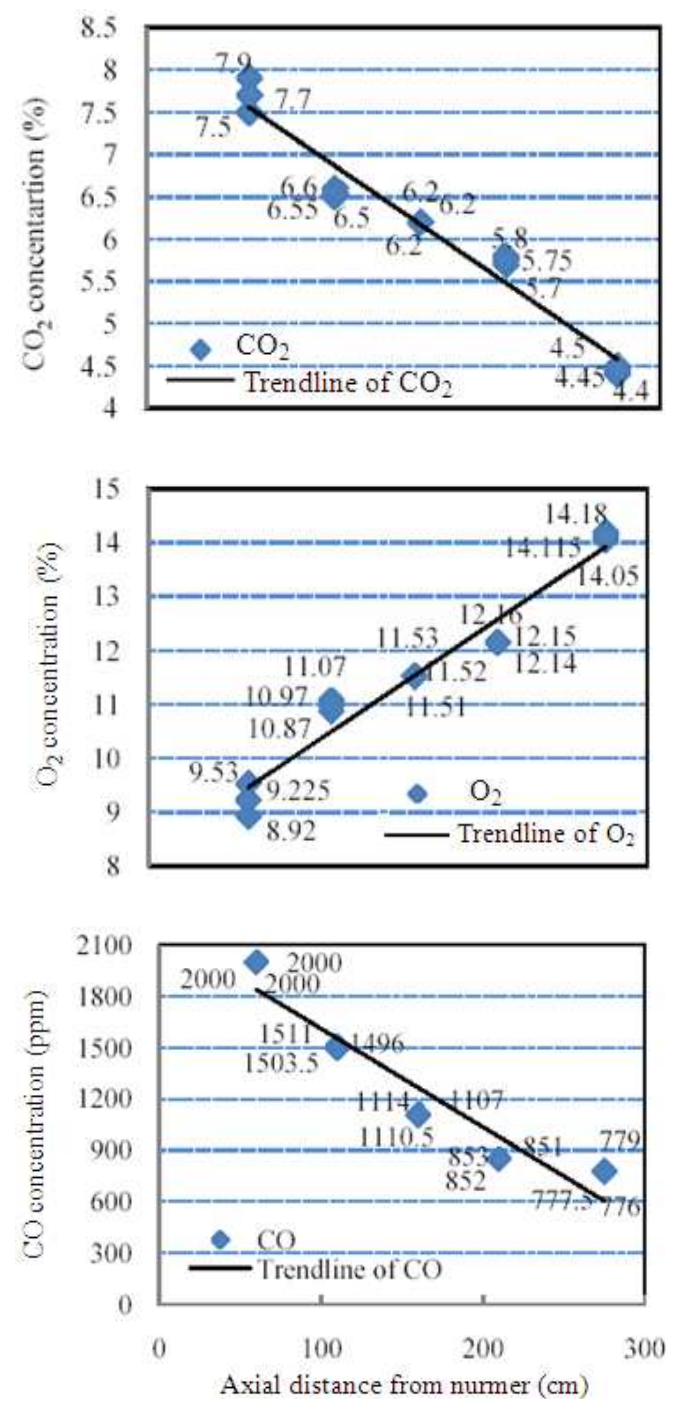

Fig. 11: $\mathrm{CO}_{2}, \mathrm{O}_{2}$ and $\mathrm{CO}$ emission formation
Carbon and oxygen component: Hydrogen and carbon were the main component inside fuel. Carbon monoxide (CO) was created as incomplete oxidation of normal result of flame, carbon dioxide. High flame temperature and initiate of air and fuel mixing are the essential for low formation of CO (Kenneth et al., 1975).

Figure 11 shows the formation of $\mathrm{CO}, \mathrm{CO}_{2}$ and $\mathrm{O}_{2}$ in the flame. In the combustion, carbon in the fuel oxidizes through a series of reactions to form carbon dioxide. However, it is impossible of $100 \%$ conversion of carbon to $\mathrm{CO}_{2}$. $\mathrm{CO}$ emission primarily results from incomplete combustion due to poor combustion and firing condition. Limited time in the rich zone of combustion process caused incomplete formation of $\mathrm{CO}_{2}$ which created the high value for $\mathrm{CO}$. This concentration will decrease by the increase length from the burner. Proper of modification in ratio of air and fuel mixing patterns will reduce the $\mathrm{CO}$ formation. Concentration of $\mathrm{CO}_{2}$ varying from 7.9-4.4\% while concentration of $\mathrm{CO}$ as incomplete oxidation was gained from 2000-776 ppm in $275 \mathrm{~cm}$ horizontal length from the centre of burner. Length of combustion flame and limited reaction region affects to the formation $\mathrm{CO}_{2}$ and $\mathrm{CO}$.

\section{CONCLUSION}

An experimental study was conducted on the laboratory scale for liquid coal fuel combustion process and exhaust gas formation. Detail of combustion process, beginning from the preparation of the system for fuel line, the heating system and the boiler setting for steady combustion of liquid coal have been explained. The side product of combustion which contributes to the formation of emission and pollution was also investigated. The particulate component was measured at $0.948 \mathrm{~g} \mathrm{~m}^{-3}$ in $60 \mathrm{~cm}$ from the centre of the burner to $0.179 \mathrm{~g} \mathrm{~m}^{-3}$ in the $275 \mathrm{~cm}$ from the centre of the burner. While the $\mathrm{NO}_{\mathrm{x}}$ component was measured at 396-242 ppm. From this experiment, by good preparation for steady combustion, there is a chance for the substitute of derivative fossil fuel with coal fuel with no special treatment is needed.

\section{ACKNOWLEDGMENT}

The researchers wish to thank you Okamoto Hiromi, Okada Hideaki and Saito Mariko from the JFE Chemical Co.Jp for collaboration project for liquid coal fuel combustion.

\section{REFERENCES}

Heywood, J.B., 1988. Internal Combustion Engine Fundamental. 1st Edn., McGraw Hill Inc., New York, pp: 601. 
Kenneth, R.J., L. Nielsen, C.T. Crowe and D.T. Pratt, 1975. Attempt to reduce Nitrogen Oxide $\left(\mathrm{NO}_{\mathrm{x}}\right)$ emission from pulverized coal furnance. Environ. Sci. Technol., 9: 859-862. DOI: 10.1021/es60107a003

Lian, Z., Y. Ninomiya and T. Yamashita, 2006. Occurrence of inorganic elements in condensed volatile matter emistted from coal pyrolysis and their contributions to the formation of ultrafine particulates during coal combustion. Energy Fuel, 20: 1482-1489. DOI: 10.1021/ef050429h

Masaharu, N., 2003. Effect of peroxides during pretreatment for coal liquefaction. Energy Fuel, 17: 506-510. DOI: 10.1021/ef020121f
Michael, C. and E. Lester, 1994. Characterization of coal for combustion using petrographic analysis: A review. Energy Fuel, 73: 315-320. DOI: 10.1016/0016-2361(94)90081-7

Pollack, S.S., 1979. Estimating mineral matter in coal from its major inorganic elements. Fuel, 4: 249-267. DOI: 10.1016/0016-2361(79)90061-9

Rajender, G., 2007. Advanced coal characterization: A review. Energy Fuel, 21: 451-460. DOI: $10.1021 /$ ef060411m 